\title{
Mission to the Gentiles: The construction of Christian identity and its relationship with ethics according to Paul
}

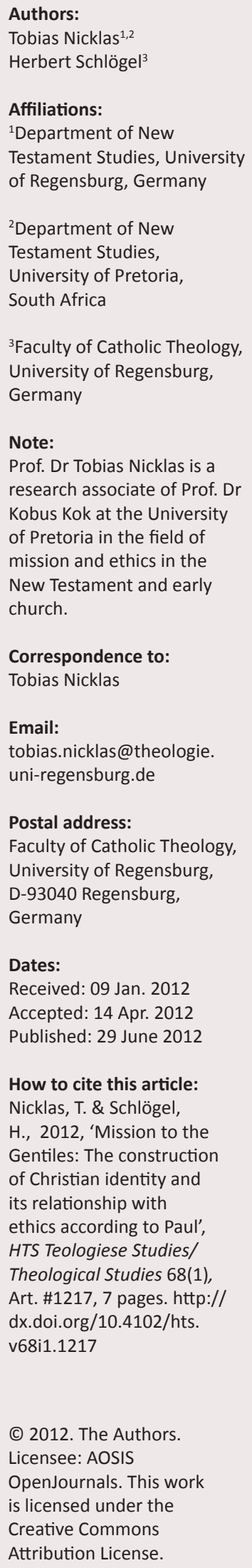

Paul allowed pagans to become members of the newly founded communities of Christ-believers and thus members of God's covenant people, Israel, without becoming circumcised. However, even if many of the 'pagan Christians' who became members of the new messianic movement had a background as God-Fearers in the frame of diaspora synagogues, the radicalism of their 'step in faith' can hardly be overestimated. With their turn from different pagan cults and their gods to the mysterious God of Israel and his crucified and risen Son, Jesus Christ, a whole coordinate system of human relationships, expectations, hopes and norms must have changed. This paper explores the construction of Christian identity and its relationship with ethics according to Paul. It is illustrated how Paul himself describes the system of changed relationships: turning away from the idols towards the living God, being in Christ or - together with others - part of the 'body of Christ'. Moreover, these three dimensions of new relations to God, to Christ and to the fellow believers in Christ - correspond to three reference points for ethical decisions in Pauline communities: the command to love one another, the idea of human conscience (as a voice coming from God) and the idea of the 'ethos of Christ'.

\section{Introduction}

As is well-known, contrary to most other Christian missionaries, Paul allowed pagans to become members of the newly founded communities of Christ-believers without being circumcised. Even if some or many of the 'pagan Christians' who joined the new messianic movement had a background as God-Fearers in diaspora synagogues, the radicalness of their step can hardly be underestimated. With their turn from different pagan cults to the mysterious God of Israel and his crucified and risen Son, Jesus Christ, a whole system of human relationship, expectations, hopes and norms must have been changed. If we read later pagan critics of Christianity like Kelsos and Porphyry or Christian apologetics like Justin Martyr or Minucius Felix's Octavius, we can imagine what it must have meant to become a member of the Christian movement, adhering to a God without an image and obviously too weak to save even his own son from a death as a criminal. Paul himself speaks about 'the scandal of the cross' (1 Cor 1:18), which puts all kinds of human wisdom and power into perspective, an idea that must be seen as at least one key to his own ideas of preaching the Gospel. ${ }^{1}$

Pauline mission thus had to achieve a radical change of the 'identity' of people who were becoming believers 'in Christ'. In this way, we are coming closer to our main topic - the relationship of Pauline 'mission' and 'ethics' in the new communities. A group's (or a person's) identity is deeply connected to matters of 'ethics', as Van der Watt (2006), for example, states: ${ }^{2}$

Identity relates to the question: 'Who are you?' Identity refers to who a person or persons regard themselves to be and why. A person's identity has a direct and determinative influence on what follows, namely ethics and ethos ... Ethics relates to the question: 'according to which rules are you and your group acting and why?' This is the 'ought to' or 'should' question. It is understood as the motivated 'rules/principles/ basic exhortations/ethical pointers' presented in a particular document, like 'love one another', which are based upon and related to the identity of a person. (pp. vi-vii)

In the rest of the article, we want to indicate how the Pauline mission tried to create a new 'identity' with Christ-believers and the role which 'ethics' played in the establishment (and development) of this identity.

\section{Mission to pagans: A changing system of 'relationships'}

As the following texts will show, people who became members of a Pauline community had to start a new life in a new 'identity-in-relationship(s)'. In other words, they had to redefine the 'relationships' which were important for their lives in a radical manner. These included that the 1.For a broader evaluation of the passage and its impact for Pauline theology cf. for example Schnelle (2003:206-218).

2.For an overview of other definitions of Christian identity, see Holmberg (2008:5-27). 
relationship with 'God' and 'Christ' and then, closely related to this, the relationships to other members of the community had to become decisive.

\section{The relationship with God}

An important text regarding the first dimension - the relationship with God - is 1 Thessalonians 1:9-10. ${ }^{3}$ Even if it is not possible to give a full exegesis of this text, at least some points should be mentioned:

- Using the verb غ̇ंı $\sigma \tau \rho \dot{\varphi} \varphi \omega$, which in later Christian literature became a technical term for 'conversion', ${ }^{4}$ Paul describes a radical turn in a person's life. The Thessalonians turned towards God, that is the God of Israel, and away from the $\varepsilon$ ¿i $\delta \omega \lambda \alpha$, the 'idols'.

- The vocabulary used also makes clear that this conversion meant a transition into the sphere of 'life' and 'truth' (cf. parallels in early Jewish texts like Joseph and Aseneth 11:10f. and Tob 14:6). God is 'living' and 'true', 5 and He has raised his son, Jesus, from the dead, obviously into an existence in the heavens, which allows Him to become the 'saviour' of the community in the coming time of 'wrath'.

- If we read this passage against the background of Old Testament texts dealing with 'idols', the relationship becomes even clearer: 'idols' are 'no-things' (Is 41:29); they will be destroyed (Is 10:11; Ezk 6:4-6; Hs 8:4), according to some texts even by God himself (Mi 1:7; Zch 13:2), or thrown away (Is 30:22); they are dead and useless (Hab 2:18-20). Of course, we may not expect pagan converts to the 'Christ-movement' to have had all these Biblical ideas in mind. ${ }^{6}$ The Christian Jew Paul, however, was conscious about this background.

Turning away from the 'idols' must, however, have been extremely difficult in a world where they were present at every corner (and in everybody's home). The fact that they still were a threat to the newly formed communities can be seen in the famous discussion about food offered to idols (1 Cor 8; 10:14-11:1; Rm 14:1-23). For the community of Corinth, the question whether it was allowed to eat meat sold at a pagan temple or offered at a banquet of (pagan) friends applied to their actual daily lives. Could it not be argued that there is only one God and there are no 'idols' in this world (1 Cor 8:4)? This would mean that eating food offered to idols would not make any difference. Would it be necessary to forego all friendships and relationships with pagans because it was possible to get food offered to idols at their meals (1 Cor 10:27)?

3.For my following argument, it is not relevant whether 1 Thessalonians $1: 9 \mathrm{~b}-10$ goes back to an older pre-Pauline Christian confessional tradition or not. For an examples of a critical discussion of the topic, see Wanamaker (1990:84-89).

4.For the use of this verb in early Christian literature, see Lampe $\left({ }^{20} 2007: 535-536\right)$. Paul himself does not use the verb very regularly. The only other instances are 2 Corinthians $3: 16$ and Galatians 4:9, but see Acts $3: 19 ; 9: 35 ; 11: 21 ; 14: 15 ; 15: 19$; 26:18-20. For a comparable use in the LXX, see Psalm 21:28; Isa 19:22; Hosea 5:4; $6: 1$; Joel 2:13.

5.For a broader understanding of the use of the epithet $\theta \varepsilon$ ò $\varsigma \zeta \tilde{\omega} v$ in Hellenistic Jewish propaganda and for parallels in early Christian literature, see the texts mentioned by Malherbe (2004:120): Daniel 5:23 LXX; Bel 5; Jub 21:3-4 et al., who (p. 121) also mentions a lot of Hellenistic Jewish parallels to the expression 'true God'.

6.For a list of pagan texts also speaking negatively on idols, see Malherbe (2004:120).
1 Thessalonians 1:9-10 answers neither the question concerning the concrete meaning of 'turning away from the idols' nor the meaning of conversion towards the God of Israel or how it changed believers' lives. The text gives only

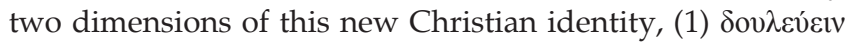

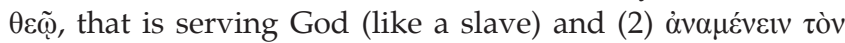

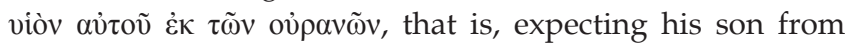
heaven. Describing a slave's total obedience to his master, the

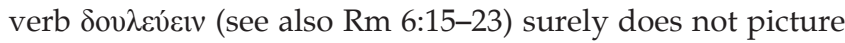
a very attractive kind of activity. The emphasis of the phrase, however, seems to be on $\theta \varepsilon \tilde{\varphi}$. That means that the believers, who had been slaves of the dead idols before, are now doing service to the true and living God. Whilst dimension (1) speaks about a new relation to God (2) adds a Christological dimension with its mainly focus on the future. Although 1 Thessalonians 1:10 focuses on the believer-God relationship and accentuates the future aspect of the believer-Christ relationship, ${ }^{7}$ it already describes two main dimensions of relationships that define the 'new' identity of a pagan 'Christbeliever'.

Another expression describing the believers' new relationship with God is their designation as 'holy' as we find it in Romans 15:25-26, 31; 1 Corinthians 1:2; 6:1-2; 14:33; 16:15; 2 Corinthians 1:1; 2 Corinthians 8:4; 9:1, 12; Philippians 1:1, et cetera (see also the deutero-Pauline Eph 1:1 and Col 1:2). In his commentary on 1 Corinthians, Zeller (2010) describes the impact of this designation in the following way:

Gemäß der prophetischen Verheißung (vgl. Jes 4, 3; 62, 12) stellt Gott am Ende sein Volk in Heiligkeit wieder her und übergibt 'den Heiligen des Höchsten' Herrschaft und Gericht (vgl. Dan 7, 18.22; diese Tradition in 1 Kor 6, 1-3 ...). Das heißt aber auch, dass an unserer Stelle der Indikativ im Vordergrund steht: Heilig sein bedeutet: Gott angehören. Die angeschriebenen Christen sind schon Heilige durch den bei der Taufe verliehenen Geist Gottes, wie noch einmal aus der ... Passivform 'Geheiligte' hervorgeht. (pp. 73-74)

In other words, describing the believers as 'holy ones' or as the ones 'made holy' by God's spirit creates a marker of a new identity which is defined by a very special relationship with God, an identity which can be compared to Israel's identity as God's Chosen People, or perhaps even more: an identity as God's people in the decisive eschatological period.

This special 'holiness' can also be expressed in terms of Schekhina: as God dwells amongst his people (Ezk 37:26-27; Lv 26:11-12), the members of the Corinthian community can be called 'God's Temple'. The author says, 'Do you not know that you are God's Temple and that God's Spirit dwells in you? If any one destroys God's Temple, God will destroy him. For God's Temple is holy, and that temple you are' (1 Cor 3:16-17; see also 2 Cor 6:16; Rm 8:9). ${ }^{8}$

\section{The believer's relationship with Christ}

Even if the list of texts speaking about the believers' holiness is quite impressive (and surely not complete), in many 7.For a new evaluation of this dimension, see Luckensmeyer (2009).

8.For an overview of the early Jewish theology of Schekhina and its development, see Frankemölle (2006:155-168). For more information on Paul's use of cultic metaphors, see Hogeterp (2006). 
Pauline arguments the relationship between believer and Christ seems even more important. Believing in Christ

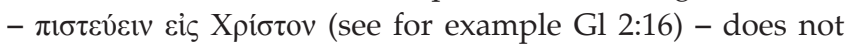
only mean to accept certain truths about Christ (even if 1 Cor 15:3-5 formulates a very early Credo), but to establish a relationship which radically changes the believer's existence.

As far as I understand this, according to Paul, the believer virtually becomes a part of Christ and Christ a part of him. That's why Paul can say that it is not he who lives, but Christ who lives in him (G1 2:20) ${ }^{9}$ or that being baptised means to be crucified with Christ (and to be united with him at his resurrection) (cf. Rm 6). That is why images, like the idea of the believer being 'in Christ', are meant very concretely.

Being 'in Christ', however, changes another relationship fundamentally: The believer is never only in relationship with Christ but also with other believers who are 'in Christ'. The fact that their identities should now be fully determined by their Christ-relationship forms the basis of the idea that distinctions outside their identity as believers should not really count anymore. One of the clearest examples for this notion is Galatians 3:26-29 where we read that believers are 'clothed' with Christ (G1 3:27). What we perhaps would call a (mere) 'symbol' used in baptismal rites until today should be understood as a 'reality' for Paul. Being 'in Christ' or being 'clothed with Christ' makes the impossible possible. It is the only reason why seemingly irreconcilable differences between Jew and Greek, slave and free man or man and woman do not count any more. Put even better: They are not there anymore: 'There is neither Jew nor Greek, neither slave nor free man, neither man and woman, because all of you are one in Christ' (Gl 3:28).

It is this idea about the believers' Christ-relationship that allows Paul to refer to believers as 'co-buried with Christ through their baptism' and to refer to baptism as 'baptism into his death' (both Rm 6:4). Moreover, the idea of the believers' being 'in Christ' can be connected to their identity as 'new creation' which possibly finds its best expression in 2 Corinthians 5:17: 'So that, if anyone is in Christ, she or he is a new creation; the old passed away, behold the new has come' (see also Gl 6:15; Rm 6:4). The 'new' identity of being a Christ-believer, being 'in Christ', is not just a formula or a symbol but has ontological consequences - the believer is a 'new creation'. ${ }^{10}$

In these ways, being 'in Christ', of course, also works as a boundary marker against outsiders. A community where the

9 .For an interpretation of this passage, see for example Baumert (2009:49) who writes: 'Die hyperbolische Redeweise beschreibt ein Verhältnis eigener Art: Er hört auf, über sich selbst eigenmächtig zu verfügen, sondern gibt die Führungsrolle dem, dessen Willen er nun tut. Und indem Paulus sich selbst zurücknimmt und Christus die erste Stelle gibt, kann ER SEIN Leben in Paulus entfalten. Plastisch ist damit ausgedrückt, auf welcher Basis Paulus nun lebt. Denn Christus lebt nicht statt seiner; er schiebt Paulus nicht beiseite, sondern ist nun der Ermöglichungsgrund für dessen eigene Lebensvollzüge.'

10.Baumert (2008:116) describes the ethical dimension of this passage in the following way: Christus ist anstelle von allen gestorben, damit diejenigen, die sich darauf einlassen und infolge ihres Mitsterbens in einem neuen Leben sind, als Lebende nun aus dieser Quelle leben und folglich sich auch, neu' verhalten. Und in V. 17 sagt er nicht: wenn einer in Christus ist, dann verhält er sich anders als vorher V. 17 sagt er nicht: wenn einer in Christus ist, dann verhält er sich anders als vorher
(ethisch), sondern ist er ein ,neues Geschöpf' (ontisch). Das ist die Grundlage, auf (ethisch), sondern ist er ein ,neues Geschöpf' (ontisch). Das ist
der ein ,neues' Verhalten (ethisch) möglich wird und aufbaut.' usual distinctions and hierarchies do not count any more (or should not count any more) creates a new distinction. Whilst there is (or in reality: there should be) neither Jew nor Greek in the community, there is, of course a difference between 'Christian' and non-Christian. Being part or not part of this very special community makes the decisive difference.

\section{Being 'in Christ' and being part of a 'Body of Christ': Mutual relationships}

The new 'Christian' identity in relationship with God and to Christ, however, should never be misunderstood as something that addresses mainly the believing individual. Being 'in Christ' always means sharing this 'identity in relationship' with others. In other words, being 'in Christ' means being part of a community of believers who are a 'body of Christ' (1 Cor 12:12-31, esp. 12:27, and Rm 12:4-5) and who call each other 'brothers' and 'sisters'. ${ }^{11}$ The 'new identity in relationship' to Christ thus renews and redefines the believer's relationships to his or her fellow believers, an idea which is also expressed in Galatians 3:26-29 mentioned above.

Of course, these ideas describe an ideal. Pauline letters tell us that more often than not the corresponding reality was quite different. In other words, Paul's description and/or creation of an idea of new identity-in-relationship was surely not always identical with the images believers created about their identity. Moreover, 'identity' is not necessarily something stable but can be subject to changes over the course of a person's life - not only in the radical way of a conversion but also by growing through processes of learning. ${ }^{12}$ And in addition to this, a person's idea of his or her identity in a certain context can be quite different from the same person's idea in another context of his or her life. In other words, a person acting as a 'Christ-believer' in the gatherings of the community can behave as an ice-cold businessman when he is doing his job. His new identity in relationship with Christ thus influences only parts of the person's life.

The difficulties of creating learning processes which make it clear that the identity of being 'in Christ' covers all areas of a Christian's life can be seen quite well in Paul's Letter to Philemon. ${ }^{13}$ In the introduction to this letter, Paul makes it very clear that he holds Philemon (and the community in his house) in high regard. He calls Philemon a 'beloved coworker' (Phlm 1), speaks about Archippos as his 'comrade' (Phlm 2) and virtually creates a network of brothers and sisters being in community with each other, because all of them are 'in Christ'. Whilst we cannot be sure what the concrete problem concerning Onesimus was, whether he was a runaway slave or had been in trouble only with his

11.For a comparison of this use with documentary papyri of Paul's times, see ArztGrabner (2003:112) who writes: 'Die von Paulus verwendeten Bezeichnungen

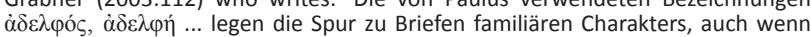
Paulus die Bruder- bzw. Schwester-Anrede nicht im wörtlichen Sinn verwendet.'

12.For this dimension of identity applied to the early Christian movement, see Meyer (1986)

13.For a more detailed interpretation of Paul's argument in Philemon, see Nicklas (2008). 
owner, Philemon, ${ }^{14}$ Paul's central argument seems to relate to the fact that Onesimus' identity has changed totally after his conversion and baptism (Phlm 10). The one who had

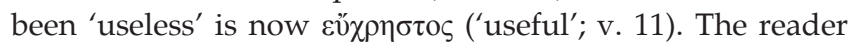
surely is expected to hear the allusion to Xpıбós in this term. Moreover, he must be seen as Paul's child now (v. 10), his 'own heart' (v. 12). Because both of them are 'in Christ' now, that is why Philemon should treat him as his 'beloved brother' (v. 16), not as his slave. Paul thus does not give concrete ethical commands telling Philemon how he has to behave against Onesimus. Onesimus' new relationship with Christ (and to Paul), however, creates a new relationship with Philemon. If Philemon, the slave-owner, wants to act as a Christ-believer whilst he remains a slave owner, he has to treat the Christian slave Onesimus as his brother 'in Christ' even in contexts which are not directly connected to Christian community life.

\section{Changing principles for ethical decisions}

With the fact that he and his co-missionaries did not expect the new believers to be circumcised, the Pauline idea of a mission to the Gentiles created a major problem for the identity of his churches. Some laws of the Torah worked as 'boundary markers' and helped Jewish or Christian-Jewish communities to define their identities against outsiders, and the Torah as a whole can be understood as the expression of how to live one's life in relationship with God who elected Israel and made it his very own people. How was it possible to express a relationship with this God if one was obviously not part of God's Covenant with Israel but member of a Pauline community of pagan Christians?

This new background made it necessary to redefine not only the believers' identity in the relationship with God, Christ and their fellow believers. It also made it necessary to redefine God's (and Christ's) will for behaviour that is appropriate to this system of relationships.

Of course, now and then Paul gives lists with rules for correct behaviour (cf. for example Rm 12:9-21 and 1 Th 5:12-22) or catalogues of virtues like Galatians 5:22-23 and Philippians 4:7-9. Additionally, in Galatians these virtues are distinguished from the (negative) 'works of the flesh' (G1 5:19-21). However, these lists alone are surely not enough for creating Christian 'ethics' in the relationship with God, Christ and fellow believers - other techniques are needed. I would like to introduce three of them. Interestingly, each of these three can be connected to one of the dimensions of mutual relationship addressed above.

\section{The Love Command}

To my mind, the first technique has to do with mutual relationships between the members of the community. If we take a closer look into at least some of Paul's ethical example Wengst (2005:30-44). arguments, it becomes clear that he actually did not totally abandon the 'law' in his pagan Christian communities. At least in some of his ethical discussions, he comes back to the idea of a fulfilment of the law and gives, comparable to Jesus (see Mk 12:28-31 par.), a central commandment to fulfil the whole of the law. However, in this context, it is interesting that he concentrates on Leviticus 19:18 about the love of one's neighbour and does not speak about Deuteronomy 6:5 concerning the love of God. One of the clearest examples is Galatians 5:14 where - at the end of a letter full of the harshest criticism of opponents expecting the Galatians to become circumcised - he writes that the entire law is fulfilled in one word: love your neighbour as yourself' (Gl 5:14). We can compare this to Romans 13:8-14 where we find the words, 'whoever loves the other has fulfilled the law' (Rm 13:8b). A few lines later, he adds some of the Ten Commandments (Ex 20:13-17; Dt 5:17-21) and again states that 'all these commandments are summed up in one word: love your neighbour as yourself. Love does not harm the neighbour. Therefore love is the fulfilment of the law' (Rm 13:9b-10). At least in the context of these writings, the main focus of the love command seems to be connected to mutual love within the community. Even if Romans 13:8a speaks about any kind of debts which should not be left outstanding, the formulation of the love command in 13:8b reads as follows: 'love one another' ( $\alpha \lambda \lambda \hat{\eta} \lambda \mathrm{ov \varsigma}))^{! 5}$

\section{The Relationship with God}

Even if the concept of 'human conscience' seemingly does not play a major role in Paul's concrete ethical arguments, it should be mentioned here because of its enormous Nachgeschichte. If the Torah is the expression of a relationship between the Israelites and their God, that is God's word to Israel about his will, the question emerges which dimension of ethical argument expresses this relationship in a context where the Torah loses (or changes) its importance. My thesis is that, at least in Romans 2:12-16, the idea of human conscience replaces the idea of a God speaking to Israel in the Torah. It is exactly this new situation of speaking to pagan Christians, who are not circumcised members of the Covenant, that makes it necessary to emphasise the idea of human conscience as strongly as Paul does.

In other words, Paul's idea of human conscience can be understood as an internalisation and a democratisation of the Torah. Whilst the written Torah can be read in the Books of Moses and the oral Torah can at least be discussed amongst the Rabbis, Paul understands human conscience as an internal Torah where God speaks (more or less) directly to the human being. And whilst the Torah is an expression of God's Covenant with Israel, God speaks to every human being via his or her conscience.

15.Even if 1 Corinthians $12-13$ does not give direct ethical commands but discusses the relationship of the different charismas to the whole of the community as 'body of Christ', 1 Corinthians 13 goes into a somewhat parallel direction. All the charismas the Corinthians are proud of are 'nothing' and 'useless' (1 Cor 13:2-3) if one does not have 'love'. In contrast to the texts mentioned above, Paul does not connect 'love' to the fulfillment of the law. He also does not speak about love of one's neighbour or love of God, but simply about 'love' - perhaps a sign that Pauline ethics is not only related to inner-community questions? 
This overall thesis is based on the following observations: ${ }^{16}$

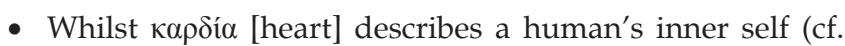

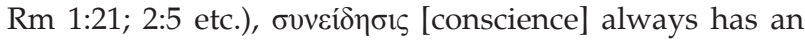
additional dimension; it represents a relationship with

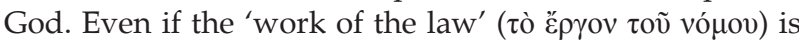
written into the 'hearts' of the members of the 'nations' $\left({ }^{\prime} \theta v \eta\right)$, it is their 'conscience' which bears witness to them, 'accusing or even defending them' (see Rm 2:15). Human 'conscience' is thus something which is not only part of the human being but in a certain sense also counterpart. For Paul, this witness is more than just an 'inner voice' related only to a person's education or societal background. This can also be seen in 2 Corinthians 1:12 where Paul speaks about the testimony of his own conscience. ${ }^{17}$ It is his conscience that bears witness to him that what he has

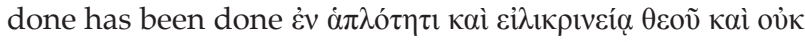

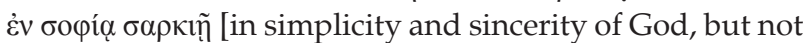
in fleshly wisdom]. The whole phrase would have been even stronger if the original reading of the text was $\dot{\varepsilon} v$

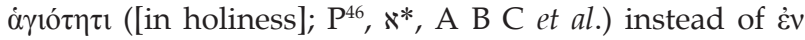
$\dot{\alpha} \pi \lambda \operatorname{co}_{\tau \eta \tau}$. If his conscience bears witness to him that what he does is happening 'in holiness' (or, as he later says, 'in God's grace'), it cannot be only an inner-human voice but must be related to God Himself.

- The relation between Romans 2:14 and 15 clarifies the contents of this witness. The Gentiles can be a 'law for themselves even if they do not have the law' (Rm 2:14). The witness of human 'conscience' thus is nothing other than an expression of God's will, that is the 'law', coming from inside the human being but also representing its counterpart. Wilckens (1987) writes:

Was das Gewissen bezeugt (Röm 2,15), ist Gottes Forderung, inhaltlich identisch mit dem, was das Gesetz den Juden sagt (V 14): das Gute, das zu tun ist $(12,2)$, im Gegensatz zum Bösen, dem Gottes Zorn gilt (Röm 13,5). So ist das Gewissen nichts anderes als das ins Herz geschriebene Gesetz (Röm 2,15a). (p. 139)

- The connection between Romans 2:15 and 16 makes clear that human 'conscience' accusing and defending a person must be related to God's final judgment. In other words, what is happening in human 'conscience' can be compared to a court case taking place within a human being. This can be related to the final court case at the Day of the Last Judgment, but does not fully anticipate its final outcome because the final decision remains with God who judges 'according to my Gospel through Christ Jesus' (Rm 2:16; cf. also 1 Cor 4:4).

With Paul's use of the idea of a human 'conscience', an old boundary can be broken down. Even if God spoke to Israel in very special ways and even if Israel will remain his Chosen People forever (see Rm 9-11), he not only spoke to Israel but speaks to every human being. This is happening - perhaps not directly, but mediated via his or her conscience. With this, it is possible to argue that even Christian communities that do not observe the Torah are able to do God's will.

16.For the following units, compare also the points expressed by wilckens (1987:138-139).

17.2 Corinthians 1:12-14 is a very difficult passage. For an excellent analysis of its syntax, see Baumert (2008:249-53).
A second, for Paul perhaps more important, ethical standard corresponding to the believer-God relationship is the exhortation to live 'in holiness' and the request of 'sanctification' (see, e.g. 1 Th 3:13; 4:3, 4, 7; 5:23). Perhaps the most interesting passage is 1 Thessalonians $4: 3-7,8$, a text framed by the following sentences:


This is namely God's will, your sanctification ...

and

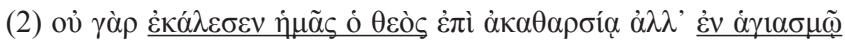
(1 Th 4:7).

For God did not call us for impurity, but in sanctification ...

Both sentences not only speak about the believers' sanctification, but connect it to the believer-God relationship, mentioning the will of God - the holy one! - or his 'calling' of the believers. Whilst the verses between $4: 3$ and 7 give concrete ethical exhortation (on matters of sexuality), 4:8 comes back to the question of the 'believer-God' relationship: '... the person who rejects this rejects not man but God ...' (1 Th 4:8a).

In addition to this, 1 Thessalonians 4:3-8 wants to create a difference, an ethical boundary marker in relationship with outsiders. The (here male) believers should learn how to acquire their own wives 'in holiness and honor, not in lustful passion as the pagans do who do not know God' (1 Th 4:3b-4; translation Malherbe). Interestingly, Paul's teaching here is more or less working with typical Early Jewish prejudices about pagan behaviour. ${ }^{18}$ The Christian Jew, Paul, asks the pagan Christian community not to behave in the way Jews think about pagan behaviour. The reason for that is their new relationship with God.

\section{The 'Mind' of Christ}

However, as far as I understand Pauline theology, the most important relationship for the believer is his or her relationship with Christ. As I see it, several important ethical guidelines, which developed from the relationship between Christ and the believer, could be discussed. I would like to mention at least one. ${ }^{19}$

In his 2005 monograph Paulus und die Gesinnung Christi, Strüder argues that 1 Corinthians 2:16c can be seen as a key

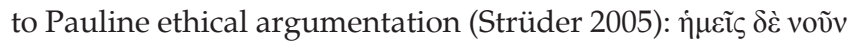

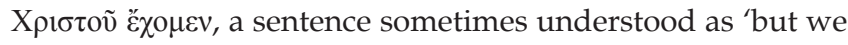
have the spirit of Christ' ${ }^{20}$ However, the fact that Paul speaks about the $\pi v \varepsilon \tilde{u} \mu \alpha$ several times in this context makes it quite obvious that $\pi v \varepsilon \tilde{v} \mu \alpha$ and $v o \tilde{v} \varsigma$ have to be distinguished here.

I cannot give a full outline of Strüder's argument, but perhaps a few points can be helpful. In his analysis of 1 Corinthians $1-4$, Strüder not only shows the fundamental integrity of these chapters but also demonstrates the importance of the term voṽ for the whole of the argument (cf. Strüder 2005:9-132). One 18.Cf. the parallels quoted by Malherbe $(2000: 226)$. 19.According to Schnelle (2003:629-45), Pauline ethics as a whole is based on the background 'Leben im Raum des Christus'.

20.See for example the important German Einheitsübersetzung. 
of his particularly important observations is that Paul uses

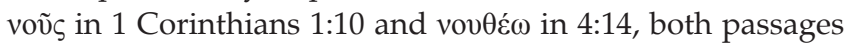
indicating the purpose of the whole unit. 1 Corinthians 1:10, where Paul exhorts the community to stay 'in the same voṽ s', is perhaps of particular importance. In 1 Corinthians 2:16, moreover, Paul's saying about the voṽ $\mathrm{X} \rho ı \tau \tau$, can be found exactly at the crossover between the argumentative part (1 Cor 1-2) and the applicative part (1 Cor 3-4) of the text (cf. Strüder 2005:165-72).

What is the exact meaning of voũ $X \rho ı \sigma \tau o \tilde{v}$ ? Strüder understands the Greek voũ $̧$ as a human being's fundamental ability to reach adequate decisions and to communicate insights. ${ }^{21}$ According to him, voṽ $\mathrm{X} \rho\llcorner\sigma \tau o \tilde{v}$ describes a competence to render (mainly) ethical judgements determined by Christ. ${ }^{22}$ Strüder thus translates voṽ $\mathrm{X} \rho \iota \tau \tau$ ṽ as 'Gesinnung Christi', which could perhaps be understood as 'Christ's ethos' or (perhaps better) 'Christ's mind'. What does this mean concretely? The fact that Paul's proclamation of the crucified Christ forms the argumentative centre of 1 Corinthians 1-4 helps to fill the term with meaning. Speaking about the voṽ $s$ of Christ creates an ethical standard, a benchmark which helps to understand weakness as power, foolishness as wisdom and the seemingly worthless as elected. ${ }^{23}$ Being 'in Christ', 'called by God' or being part of the 'body of Christ' thus means to judge matters not according to human and worldly standards, but according to principles which are assessed by the believer's relationship with Christ, his or her having the 'voũ of Christ' which shows its deepest sense in Christ's dying at the Cross.

In this way, 1 Corinthians 2:16 is not only a key passage for 1 Corinthians 1-4 but can be understood as crucial for the whole of 1 Corinthians. With his crucifixion, Christ has shown a voṽ that should now (and always) shape the Corinthians' ethical decisions (see Strüder 2005:400-79). Being part of the 'body of Christ' (1 Cor 12), they should be in 'the same voṽ $\varsigma^{\prime}$

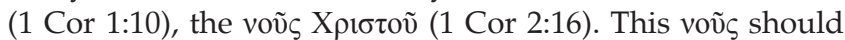
form a standard for all their ethical decisions and help to

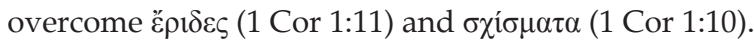

Of course, it could be argued that Paul speaks about the vov $\varsigma$

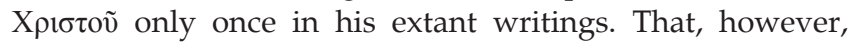
does not mean that ethical decisions using the believer's relationship with Christ as a principle of ethical decision cannot be found in other Pauline passages. Even if Strüder

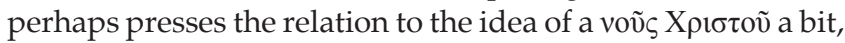
the ethical arguments in Philippians 1-2, Romans 15:1-6 and 2 Corinthians 10-13 can at least be put in a comparable line (see Strüder 2005:482-518).

21.Strüder (2005:230): 'Als grundlegende Befähigung des Menschen zur Entscheidungsfindung und zur kommunikativen Vermittlung von Einsichten ist der voũ $\varsigma$ bei Paulus an spezifische Inhalte gebunden, welche als Kriterien zu praktisch relevanter Entscheidungsfindung dienen.'

22.Strüder (2005:256): 'eine von Christus her bestimmte Beurteilungsfähigkeit ..., die in erster Linie für die Beantwortung ethischer Probleme relevant ist, auch wenn sie grundsätzlich auf alles ... gerichtet ist.'

23.'Dementsprechend beinhaltet die Gesinnung Christi einen Beurteilungsmaßstab durch den das Schwache als Kraft, das Törichte als Weisheit und das Wertlose als (ü erwählt angesehen werden kann. Der durch das Wort vom Kreuz geprägte voũ X Maßstäbe anlegt. Eine solche Gesinnung wird offenbar, wo die Gläubigen nich mehr nach üblichen Kriterien urteilen und sich auch nicht mehr nach weltlichen Gesichtspunkten beurteilen lassen, sondern ihre Welt- und Selbstsicht auf das Handeln Gottes an ihnen gründen' (Strüder 2005:299).

\section{Conclusion}

Other ideas could be added. We have not spoken about the

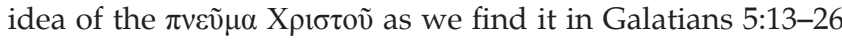
and have only touched on the important fact that believers are not just seen as being 'in Christ' but as awaiting Christ as the coming one. ${ }^{24}$ However, even if a lot of work remains to be done, at least a few conclusions seem possible.

In his important monograph on Paul's letter to the Romans, Esler (2003) describes Paul's role towards the reshaping of the identity of the Roman community in the following way: ${ }^{25}$

I am concerned with the way in which Paul sought to exercise leadership in relation to the Roman congregations by reinforcing the fundamental common identity his addressees shared in relation to God and Christ, especially to the extent that his success in such a strategy would mean creating a particular form of unity between Judean and Greek ethnic subgroups previously accustomed to mutual hostility and conflict. I am proposing that Paul was acting as an entrepreneur of identity. (p. 109)

Even if I am sure that Paul was not always (and perhaps not very) successful in his reshaping of the identities of believers addressed in his letters, I share at least two points with Esler's assessment:

- Whilst it seems to be extremely difficult (or perhaps impossible) to say anything about how Pauline Christians constructed their identity in different contexts of their lives, at least one dimension of Paul's work was to create, define, form, shape, reshape or influence believers' identities. Even if we do not know how successful Paul really was during his lifetime, the mere fact that his communities survived as Christian communities in a partly very hostile world is at least astonishing and should be seen as a great result of this process of identity-formation.

- One of the fundaments of the Pauline construction of Christian identity is the idea that Christian identity is

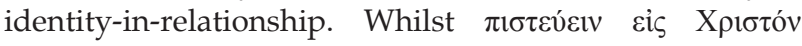
creates a relationship with Christ Jesus which, for example, can be described as being 'in Christ', it is also meant to be in a relationship with the 'true and living God' (1 Th 1:9). This relationship with the 'holy one' allows the members of the community to be addressed as 'holy'. Being 'in Christ', however, means to be deeply connected to a community of fellow believers, called 'brothers' and 'sisters', who form the 'body of Christ'. This system of positive relationships also means that other relationships are now excluded. Conversion to God means an aversion from the idols, drinking the Cup of Christ does not allow one to drink the cup of the demons; living in a community where there is neither Jew nor Greek, neither slave nor free man and neither man nor woman should at least create a boundary to groups where these differences still matter. Not to be misunderstood: I am speaking about Paul's attempts to construct Christian identities - not about the corresponding social realities.

Interestingly, the three dimensions of new shaping the identity of Pauline Christ-believers can be related quite

24.For the impact of this dimension on the ethics of 1 Thessalonians, see for example Schnelle (2003:193-196).

25.Esler (2003:109), also quoted by Holmberg (2008:16). 
clearly to principles of ethical decisions found in Paul's letters. I briefly discussed the ideas of human conscience, the believers' sanctification (both corresponding to the believerGod relationship), the 'mind of Christ' (believer-Christ) or the command to love one's neighbour (believer-believer). Moreover, these principles not only correspond to the three dimensions of believers' 'identity-in-relationship' but can be connected to concrete ethical demands.

Finally, it is perhaps possible to go one step further. If for Paul Christian identity is 'identity in relationship', it is this relationship (and its success) that makes possible justification. In this case, a text such as Galatians 2:16 could be understood in the following way. It is not the हैpy $\alpha$ of the Law that render a person justified (the focus being not on 'Law', but on है $p \gamma \alpha$ ) but rather the 'faith of Jesus Christ', that is Christ's relationship with God shown in his crucifixion and resurrection. This relationship corresponds to our $\pi \imath \sigma \tau \varepsilon v \varepsilon 1 v$

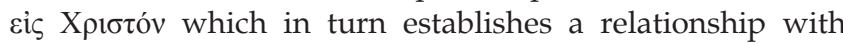
Christ and thus to God. This does not mean that believers should not love one another and thus 'do' and 'fulfil' the law (Gl 5:14). This love, however, does not save them, but it is only an expression of their 'identity in relationship' to the true and living God and his Son Jesus Christ the saviour (1 Th 1:9-10).

\section{Acknowledgements Competing interests}

The authors declare that they have no financial or personal relationship(s) which may have inappropriately influenced them in writing this article.

\section{Authors' contributions}

T.N. (University of Regensburg) and H.S. (University of Regensburg) co-authored the article.

\section{References}

Arzt-Grabner, P., 2003, Philemon, Papyrologische Kommentare zum Neuen Testament 1 , Vandenhoeck \& Ruprecht, Göttingen.

Baumert, N., 2009, Der Weg des Trauens: Übersetzung und Auslegung des Briefes an die Galater und des Briefes an die Philipper, Echter, Würzburg.

Baumert, N., 2008, Mit dem Rücken zur Wand. Übersetzung und Auslegung des zweiten Korintherbriefes, Echter, Würzburg.

Esler, P.F., 2003, Conflict and Identity in Romans: The Social Setting of Paul's Letter, Fortress, Minneapolis.

Frankemölle, H., 2006, Frühjudentum und Urchristentum: Vorgeschichte - Verlauf - Auswirkungen (4. Jahrhundert v.Chr. bis 4. Jahrhundert n. Chr.), Kohlhammer, Stuttgart.

Hogeterp, A.L., 2006, Paul and God's Temple: A Historical Interpretation of Cultic Imagery in the Corinthian Correspondence, Peeters, Leuven. (Biblical Tools and Studies 2).

Holmberg, B., 2008, 'Understanding the First Hundred Years of Christian Identity', in B. Holmberg (ed.), Exploring Christian Identity, pp. 1-32, WUNT 226, Mohr, Tübingen

Horbury, W., 1982, ' 1 Thessalonians 2, 3 as Rebuking the Charge of False Prophecy', Journal of Theological Studies 33, 492-508.

Luckensmeyer, D., 2009, The Eschatology of First Thessalonians, Vandenhoeck \& Ruprecht, Göttingen. (NTOA/STUNT 7).

Malherbe, A.J., 2004, The Letters to the Thessalonians, Yale University Press, New Haven.

Meyer, B.F., 1986, The Early Christians: Their World Mission and Self-Discovery, Glazier, Wilmington.

Nicklas, T., 2008, 'The Letter to Philemon: A Discussion with J. Albert Harrill', in S.E. Porter (ed.), Paul's World, Pauline Studies 4, pp. 201-220, Brill, Leiden. http:// dx.doi.org/10.1163/ej.9789004162723.i-284.52

Schnelle, U., 2003, Paulus: Leben und Denken, De Gruyter, Berlin.

Strüder, C.W., 2005, Paulus und die Gesinnung Christi: Identität und Entscheidungsfindung aus der Mitte von 1 Kor 1-4, BETL 190, Peeters, Leuven.

Van der Watt, J.G., 2006, 'Preface', in J. van der Watt (ed.), Identity, Ethics, and Ethos in the New Testament, BZNW 14, pp. V-ix, De Gruyter, Berlin. http://dx.doi. org/10.1515/9783110893939.v

Wanamaker, C.A., 1990, The Epistles to the Thessalonians, NIGTC, Eerdmans, Grand Rapids.

Wengst, K., 2005, Der Brief an Philemon, Theologischer Kommentar zum Neuen Testament 16, Kohlhammer, Stuttgart.

Wilckens, U., 1987, Der Brief an die Römer (Röm 1-5), EKK VI/1, Zürich, Benziger. Neukirchen-Vluyn, Neukirchener.

Zeller, D., 2010, Der erste Brief an die Korinther, KeK 5, Vandenhoeck \& Ruprecht, Göttingen. 